ALEKSANDER BOEDYREW

https://orcid.org/0000-0002-8626-9582

Instytut Historii Uniwersytetu Łódzkiego

\title{
PRZEMIANY UZBROJENIA WOJSKA POLSKIEGO NA PRZEŁOMIE ŚREDNIOWIECZA I NOWOŻYTNOŚCI (1454-1572) JAKO PRZEJAW (R)EWOLUCJI MILITARNEJ*
}

Zarys treści: $\mathrm{W}$ artykule poddano analizie przemiany uzbrojenia indywidualnego wojska polskiego na przełomie średniowiecza i nowożytności z punktu widzenia teorii rewolucji militarnej. Dowiedziono, że w omawianym okresie miała miejsce tzw. gunpowder revolution. Jest to jedna $\mathrm{z}$ cech dystynktywnych rewolucji militarnej, co więcej, można ją zaobserwować wcześniej niż w Europie Zachodniej. Mimo to na dłuższą metę nie przyniosła zmian w strukturze administracji wojskowej, a w dalszej konsekwencji w administracji państwowej.

The content outline: The article features an analysis of the changes in the armament of the Polish Army soldiers at the turn of the Middle Ages and the early modern period from the point of view of the theory of military revolution. It is demonstrated that the so-called gunpowder revolution occurred in the discussed period. It is one of the characteristic features of the military revolution, with the changes in Poland preceding similar transformations in Western Europe. Nonetheless, in the long term the revolution did not bring about changes in the administrative structure of the military and, consequently, in the state administration.

Słowa kluczowe: rewolucja wojskowa, historia wojskowości, Królestwo Polskie na przełomie XV i XVI w., uzbrojenie

Keywords: military revolution, history of warfare, Kingdom of Poland in the $15^{\text {th }}-16^{\text {th }}$ century, armament

* Artykuł powstał w ramach projektu badawczego Narodowego Centrum Nauki SONATA nr 2016/23/D/HS3/03210 pt. „Rewolucja militarna jako czynnik modernizacyjny skarbowości i organizacji państwa polsko-litewskiego na tle europejskim”. 
W rozważaniach historiografii zachodniej poświęconych zjawisku tzw. rewolucji militarnej, inaczej mówiąc wojskowej (military revolution), realia środkowoeuropejskie w zasadzie nie są obecne. Jeśli się pojawiaja. to zazwyczaj w kontekście konfliktu zbrojnego Habsburgów z Turcja, prowadzonego na obszarze państwa węgierskiego, ewentualnie zmian zachodzących $\mathrm{w}$ wojskowości państwa moskiewskiego ${ }^{1}$. Owo marginalizowanie wojskowych dziejów monarchii jagiellońskiej przejawia się przede wszystkim $\mathrm{w}$ redukcjonistycznych stwierdzeniach na temat braku odpowiedniego poziomu zaawansowania fortyfikacji na kresach południowo-wschodnich ${ }^{2}$. Formułowana jest również teza o podstawowym znaczeniu i największej skuteczności jazdy jako siły zbrojnej na stepowych obszarach wyżynnych ${ }^{3}$. Twierdzenia te, choć same w sobie prawdziwe, nie uwzględniają wielu ważnych aspektów polskiej sztuki wojennej i zdają się sugerować, że nie ma żadnych dodatkowych uwarunkowań, które warto analizować. Niedostatecznie pogłębione podejście części zachodnich historyków do dziejów wojskowości polskiej przyczynia się do powstawania wielu uproszczeń, a nawet ewidentnych błędów ${ }^{4}$.

$\mathrm{Z}$ drugiej strony przynajmniej kilkudziesięcioletnie badania prowadzone przez badaczy polskich, litewskich, białoruskich, ukraińskich i rosyjskich nad wojskowością późnośredniowieczną i renesansowa państwa polsko-litewskiego raczej nie nawiązywały do wątku rewolucji

${ }^{1}$ M.C. Paul, The Military Revolution in Russia, 1550-1682, „The Journal of Military History" 68, 2004, nr 1, s. 9-45; M. Poe, The Military Revolution, Administrative Development, and Cultural Change in Early Modern Russia, „Journal of Early Modern History" 2, 1998, nr 3, s. 247-273; V. Dangl, V. Kopčan, Vojenské dejiny Slovenska, II zväzok 1526-1711, Bratislava 1995, passim.

${ }^{2}$ R.I. Frost, W sprawie zachodniej techniki wojskowej w okresie Wojen Pótnocnych (1558-1721), w: Między Zachodem a Wschodem. Studia z dziejów Rzeczypospolitej $w$ epoce nowożytnej, red. J. Staszewski, K. Mikulski, J. Dumanowski, Toruń 2002, s. 295; tenże, The Polish-Lithuanian Commonwealth and the „Military Revolution”, w: Poland and Europe: Historical Dimensions. Selected Essays from the Fiftieth Anniversary International Congress of the Polish Institute of Arts and Sciences in America, t. 1, red. J.S. Pula, M.B. Biskupski, New York 1993, s. 26-27.

${ }^{3}$ G. Parker, The „Military Revolution”, 1560-1660 - a Myth?, „The Journal of Modern History" 48, 1976, nr 2, s. 205; tenże, The Military Revolution. Military Innovation and the Rise of the West, 1500-1800, Cambridge 1996, s. 37.

${ }^{4}$ J. Maroń, Wokót teorii rewolucji militarnej. Wybrane problemy, Wrocław 2011, s. 14 , przyp. 22 , s. 21 , przyp. 72 , s. 22,57 (w odniesieniu do wojskowości husyckiej); zob. inne uchybienia: G. Parker, The Military Revolution. Military Innovation..., s. XVI - lokalizacja na mapie Kircholmu i Kłuszyna; tenże, The „Military Revolution”, 1560 $-1660 \ldots$, s. 206, tab. 1: Increase in Military Manpower, 1470-1710 - brak monarchii jagiellońskiej i państw niemieckich; M. Bennett, J. Bradbury, K. DeVries, J. Dickie, P. Jestice, Fighting Techniques of the Medieval World, AD 500 - AD 1500, New York 2005, s. 138 - lokalizacja na mapie Legnicy i opis schematu bitwy z 9 IV 1241 r. 
militarnej rozumianego na sposób zachodni ${ }^{5}$. W efekcie powstała sytuacja, w której badania oparte na paradygmacie „rewolucyjno-militarnym” jeśli były prowadzone, to pomijały realia polskie i litewskie, natomiast te, które odnosiły się do tych terenów, nie sięgały po teorię Michaela Robertsa i jego następców. Ten stan rzeczy uległ pewnej zmianie w ostatnich latach, nadal jednak większość uwagi przyciaga XVII stulecie bądź czasy późniejsze ${ }^{6}$. Miał zatem rację Robert I. Frost, pisząc: „If progress is to be made in this debate, it will only come through the sort of detailed consideration of individual states that Parrott has given to Richelieu's France, or that Parker devoted to Army of Flanders"7. Można założyć, że potencjał badań operujacych na poziomie ogólnych obserwacji został w jakiś sposób wyczerpany. Sięgnięcie do źródeł powinno zaś otworzyć nowe możliwości.

$\mathrm{Z}$ perspektywy przemian $\mathrm{w}$ wojskowości monarchii jagiellońskiej szczególnie ważnym okresem jest przełom średniowiecza i nowożytności. Stopniowo postępująca marginalizacja pospolitego ruszenia (od przegranej przez nie bitwy pod Chojnicami w 1454 r. aż do rokoszu lwowskiego w $1537 \mathrm{r}$., kiedy to pospolite ruszenie odmówiło udziału w walce) wymusiła na panujących sięgnięcie po inne rozwiązania. Oparcie się na wojskach pieniężnych okazało się bardziej efektywne, co nie znaczy oczywiście, że bezproblemowe ${ }^{8}$. Zjawisko to wpływa na chronolo-

5 J. Maroń, dz. cyt., s. 14-15.

${ }^{6}$ Dla przykładu (w porządku chronologicznym) zob. P. Gawron, Poglady Stanisława Herbsta na rozwój nowożytnej sztuki wojennej a teoria „Rewolucji Militarnej”, w: Wojsko, wojskowość, miasta. Studia poświęcone Prof. Stanisławowi Herbstowi $w$ stulecie urodzin, red. K. Bobiatyński, P. Gawron, M. Nagielski, Zabrze 2009, s. 153-164; J. Maroń, dz. cyt.; B. Burliga, „Ordunki” versus „arkebuzy dymiace”. Tradycja i nowoczesność $w$ „Księgach o rycerskich rzeczach (Kreigsordnung)” księcia Albrechta von Hohenzollerna, w: Organizacja armii w nowożytnej Europie: struktura - urzędy - prawo - finanse, red. K. Łopatecki, Zabrze 2011, s. 47-61; K. Łopatecki, „Disciplina militaris” $w$ wojskach Rzeczypospolitej do połowy XVII wieku, Białystok 2012; J.J. Sowa, O prawnych aspektach dyscypliny w siłach zbrojnych Rzeczypospolitej. Na marginesie najnowszych prac Karola Eopateckiego, CPH, t. 66, 2014, nr 1, s. 439-450; E. Olzacka, Wojna a kultura. Nowożytna rewolucja militarna w Europie Zachodniej i Rosji, Kraków 2016; K. Łopatecki, U genezy państwowej opieki społecznej $i$ zdrowotnej - szpitalnictwo wojskowe w epoce nowożytnej, „Medycyna Nowożytna” 22, 2016, nr 1, s. 55-77; T. Srogosz, Życie codzienne żotnierzy armii koronnej i litewskiej $w$ XVII wieku, Oświęcim 2018; P. Szadkowski, Staropolskie i hiszpańskie piśmiennictwo wojskowe XVI wieku w kontekście teorii rewolucji militarnej. Próba porównania, KH, t. 125, 2018, nr 3, s. 597-631; A. Kazakou, Gunpowder Revolution in the East of Europe and the Battle of Orša, 1514 (w druku).

${ }^{7}$ R.I. Frost, The Polish-Lithuanian Commonwealth..., s. 23.

${ }^{8}$ K. Łopatecki, Organizacja, prawo $i$ dyscyplina $w$ polskim i litewskim pospolitym ruszeniu do połowy XVII wieku, Białystok 2012, s. 103-146, 189-223, 569-571. 
gię istotnych przemian w wojskowości, określanych w klasycznej teorii rewolucji militarnej na lata 1560-1660. Tendencja ta jest zauważalna w historiografii. Geoffrey Parker wybór roku 1560 jako początku rewolucji militarnej uznał za niefortunny, dowodząc, że pewne jej symptomy można dostrzec w Italii lub na Półwyspie Pirenejskim już w drugiej połowie XV w. ${ }^{9}$ Podobne stanowisko zajał Gabor Agoston w odniesieniu do imperium tureckiego, wykazując wiele zmian w jego wojskowości już w połowie XV w. ${ }^{10}$ Innymi słowy, uwagę należy skupić nie tylko na regionie Europy Środkowej, ewentualnie Wschodniej, ale warto także rozszerzyć zakres chronologiczny poszukiwań ${ }^{11}$.

Przyjęte w tym opracowaniu cezury (1454-1572) wynikaja z przekonania, że właśnie $\mathrm{w}$ tym okresie doszło $\mathrm{w}$ polskich siłach zbrojnych do znaczących przekształceń, które legły u podstawy przemian wojskowości polskiej. Nie jest to koncepcja nowa ${ }^{12}$. Cezura początkową niniejszego opracowania jest rok 1454, czyli początek wojny trzynastoletniej, przy czym ma on znaczenie symboliczne. Istota sa bowiem zmiany, które zaszły w polskiej wojskowości w czasie tejże wojny ${ }^{13}$. W ogromnym skrócie można powiedzieć, że do chwili rozpoczęcia działań wojennych (a nawet do początku lat sześćdziesiatych XV w.) podstawowa siła zbrojną Królestwa Polskiego było rycerskie pospolite ruszenie zwoływane z obszaru całego państwa (expeditio generalis) bądź jednej lub kilku prowincji (expeditio particularis) ${ }^{14}$. Pierwsza bitwa wojny, to znaczy starcie pod Chojnicami (18 IX 1454 r.), dowiodło, że w konfrontacji z przeciwnikiem dysponujacym wojskiem inaczej zorganizowanym, a co za tym idzie inaczej walczącym, rycerstwo stoi na znacznie

${ }^{9}$ G. Parker, The „Military Revolution”, 1560-1660..., s. 197, 206.

${ }^{10}$ G. Agoston, Firearms and Military Adoption. The Ottomans and the European Military Revolution, 1450-1800, „Journal of World History” 25, 2014, nr 1, s. 89.

${ }^{11} \mathrm{O}$ kwestii przyjętego okresu zob. D. Eltis, The Military Revolution in Sixteenth-Century Europe, New York 1995, s. 1-4; J. Raymond, Henry VIII's Military Revolution. The Armies of Sixteenth-Century Britain and Europe, London 2007, s. 195; J. Maroń, dz. cyt., s. 46; A. Kazakou, dz. cyt.

${ }^{12} \mathrm{~W}$ zbliżonej formie (szczególnie jeśli chodzi o cezurę początkowa) prezentował ją już M. Kukiel; zob. tenże, O podziale polskiej historii wojskowej na okresy, „Przegląd Współczesny" 7, 1928, nr 1, s. 63-81, passim; zob. też Wypisy źródtowe do historii polskiej sztuki wojennej, z. 4: Polska sztuka wojenna w latach 1454-1562, oprac. Z. Spieralski, Warszawa 1958. W tym przypadku okres zamknięto wprowadzeniem tzw. kwarty; zob. tamże, s. 5.

${ }_{13}$ M. Plewczyński, Żotnierz jazdy obrony potocznej za czasów Zygmunta Augusta. Studia nad zawodem wojskowym $w$ XVI w., Warszawa 1985, s. 23.

${ }^{14} \mathrm{~K}$. Ginter, Udziat szlachty polskiej $w$ pospolitym ruszeniu $w$ XIV $i$ XV wieku. Aspekty prawne $i$ stan faktyczny, Kraków 2008, s. 34 n. 
słabszej pozycji ${ }^{15}$. Marian Biskup pisał, że „Chojnice [...] były gorzką lekcją dla króla i dowódców polskich, posługujących się przestarzałymi już częściowo elementami sztuki wojennej i tradycyjnym rodzajem wojska"16. Klęska pospolitego ruszenia z Wielkopolski przyczyniła się do stopniowego przeniesienia ciężaru walki na tzw. wojska pieniężne. Ich skuteczności dowiodła kolejna istotna bitwa z okresu wojny trzynastoletniej - bitwa pod Świecinem (17 IX 1462 r. $)^{17}$. Zapoczątkowane wówczas przemiany nie wykluczyły całkowicie sił rycerskich z wojny, jednak stopniowo zaczęła rosnąć rola wojska opłacanego przez władcę na podstawie zawieranych z dowódcami wojsk najemnych kontraktów lub powierzanych dowódcom zaciężnych listów przypowiednich ${ }^{18}$.

Jako umowną cezurę końcową przyjęto kres panowania Zygmunta II Augusta, choć z punktu widzenia dziejów wojskowości można się spierać, czy realna reforma w tym obszarze nastapiła w momencie powołania tzw. wojska kwarcianego ${ }^{19}$, czy dopiero za panowania Stefana I Batorego ${ }^{20}$.

Badania nad uzbrojeniem wojsk pieniężnych oparte są przede wszystkim na szerokiej podstawie źródeł pisanych. Sa to typowe badania ilościowe. Charakter zachowanych źródeł, czyli tzw. rejestrów popisowych wojsk zaciężnych, determinuje zastosowanie tej metody. Spisy zarówno w przypadku jazdy, jak i piechoty zazwyczaj odnotowują uzbrojenie żołnierzy prezentowane podczas lustracji oddziałów (przeprowadzanych w momencie przyjmowania do służby). Warto zaznaczyć, że komponent ten był ważniejszy niż sami żołnierze, których np. w oddziałach jazdy na ogół (poza dowódcami i podoficerami) nie zapisywano.

Zachowane materiały są typowymi źródłami skarbowo-wojskowymi o charakterze masowym. Noszą cechy ewidentności rozumianej jako

${ }_{15}$ M. Biskup, Trzynastoletnia wojna z Zakonem Krzyżackim 1454-1466, Warszawa 1967, s. 244-269.

16 Tamże, s. 269.

17 Tamże, s. 622-632; T. Grabarczyk, Piechota zaciężna Królestwa Polskiego w XV wieku, Łódź 2000, s. 213-214; J. Szymczak, Poczatki broni palnej w Polsce (1383-1533), Łódź 2004, s. 260-261; T. Grabarczyk, Jazda zaciężna Królestwa Polskiego w XV wieku, Łódź 2015, s. 168-170.

${ }_{18}$ K. Koranyi, Żolnierz najemny a żotnierz zaciężny, CPH, t. 1, 1948, s. 105-108.

${ }_{19}$ Wojska opłacanego z kwarty, czyli czwartej części (quarta pars) dochodów z dóbr królewskich; zob. Wypisy źródtowe..., s. 5.

${ }^{20}$ Pamiętniki do historyi Stefana króla polskiego, wyd. E. Raczyński, Warszawa 1830, s. 128; zob. też VL, t. 2, Petersburg 1859, s. 190-191; H. Kotarski, Wojsko polsko-litewskie podczas wojny inflanckiej 1576-1582. Sprawy organizacyjne, „Studia i Materiały do Historii Wojskowości” 17, 1971, nr 1, s. 108-113 (cz. 2), nr 2, s. 83-99 (cz. 3), 18, 1972, nr 1, s. 33-40, 58-61 (cz. 4), nr 2, s. 72-78 (cz. 5); K. Olejnik, Stefan Batory 1533-1586, Warszawa 1988, s. 110-120, 144-145 
osobiste sprawdzenie przez inwentaryzatora faktycznego stanu rzeczy $^{21}$. Można zatem przyjąć, że metoda ich sporządzania była stosunkowo prosta: pisarz wojskowy odnotowywał stan uzbrojenia z natury. Ta pozorna zwięzłość przekazu rekompensowana jest ilością zachowanych materiałów. Do tej pory poddano szczegółowej kwerendzie i analizie ponad 30 tys. wpisów, pozostałe zaś zachowane dla omawianego okresu materiały szacowane sa na kolejne kilkadziesiąt tysięcy ${ }^{22}$. Zestawienie danych nie polega tylko i wyłącznie na zliczeniu poszczególnych elementów uzbrojenia, odnotowaniu ich pojawienia się lub zaniku. Szczególnie interesujące jest bowiem odnotowywanie zestawów broni, tzw. armatur. Częstotliwość ich występowania świadczy dopiero o celowym użyciu tych, a nie innych narzędzi walki, w zależności od zadań stawianym poszczególnym oddziałom.

Najstarszy znany rejestr wojska pieniężnego pochodzi z 1461 r. Jest to protokół lustracyjny roty Wawrzyńca Szranka ${ }^{23}$. Natomiast najnowszy poddany szczegółowej analizie dotyczy oddziału Aleksandra Kosińskiego, służącego w $1569 \mathrm{r}^{24}$ Rejestry nie uwzględniały wszystkich żołnierzy dowodnie zaciagniętych do służby. Dobrym przykładem jest sytuacja z 1538 r., w czasie letniej wyprawy mołdawskiej hetmana Jana Tarnowskiego pod Chocim. Na podstawie źródła masowe można potwierdzić udział w niej 8259 jeźdźców, podczas gdy ogólna ich liczba szacowana jest na ok. 12 tys. $^{25}$

Ze względu na kilkudziesięcioletnią tradycję stosowania terminu military revolution posługuję się tym skrótem myślowym jako konstruktem

${ }^{21}$ A. Chojecki, Oczywistość, „Er(r)go. Teoria - Literatura - Kultura” 1-2 (18-19), 2009 , s. 59.

22 Jest to 19326 wpisów dot. piechoty i 11703 wpisy dot. jazdy; zob. T. Grabarczyk, Ręczna broń palna w świetle rejestrów popisowych piechoty zaciężnej $w$ z lat 1471-1500, „Acta Uniwersitatis Lodziensis. Folia Historica” 64, 1999, s. 27-48; tenże, Piechota zaciężna..., s. 19; tenże, Jazda zaciężna..., s. 59; A. Bołdyrew, Piechota zaciężna w Polsce w pierwszej połowie XVI wieku, Warszawa 2011, s. 29; tenże, Rota piesza Antoniego Mory z 1553 r. Studium przypadku, w: Studia nad staropolskq sztukq wojenna, t. 4, red. Z. Hundert, K. Żojdź, J.J. Sowa, Oświęcim 2015, s. 15-26; tenże, Jan Ciemierzyński's Comitiua. A Preliminary Study of the History of Defence of the South-Eastern Borderland during the Poswole Expedition of Sigismund II Augustus (1557), w: War in History. The History of Polish and General Military Service, red. A. Niewiński, Lublin 2017, s. 103-114; tenże, Rota drabska pana Aleksandra Kosińskiego (1569 r.) (w druku); tenże, Przemarsz armii koronnej pod Chocim w kampanii letniej 1538 r. (w druku).

${ }^{23}$ BUW, rkps 340.

${ }^{24}$ A. Bołdyrew, Rota drabska...

${ }_{25}$ M. Plewczyński, Materiały do zagadnienia liczebności i organizacji wojska polskiego $w$ latach 1526-1547, „Studia i Materiały do Historii Wojskowości” 32, 1989, s. 264-265; A. Bołdyrew, Przemarsz armii koronnej... 
historiograficznym. Mam świadomość, że perspektywa badawcza przyjmowana w studiach „rewolucyjno-militarnych”, tzn. perspektywa długiego trwania, pozwala dostrzegać przemiany niepodatne na współczesne systematyki cezurowe, a nawet zupełnie od nich niezależne ${ }^{26}$. Warto jednocześnie zauważyć, że pojęcie military revolution sugeruje nadzwyczajną dynamikę przeobrażeń, które de facto były rozłożone na stulecia, co każe zastanowić się nad (r)ewolucyjnościa procesu przemian militarnych.

$$
* * *
$$

Jak zauważył Gabor Agoston: „the introduction of firearms led to the rise of centralized states in Europe - and, on a global scale, to the "rise of the West «"27. Juz samo to stwierdzenie nasuwa przynajmniej dwie wątpliwości w kontekście dziejów państwa polsko-litewskiego. Czy można wszakże mówić o powstaniu na obszarze władztwa królów elekcyjnych zcentralizowanego państwa, a w konsekwencji - o udziale tej rzekomo centralistycznej struktury państwowej w „narodzinach Zachodu”? Większość, jeśli nie wszystkie, doświadczenia Korony i Wielkiego Księstwa Litewskiego nie dają się przecież wpisać w ten schemat. Mówiąc inaczej, rewolucja militarna, jeśli miała miejsce w Europie Środkowej w omawianym okresie, nie doprowadziła do żadnej z wymienionych przez Agostona dalekosiężnych konsekwencji. Zagadnienie to chciałbym zarysować na podstawie badań dotyczących uzbrojenia indywidualnego, a zwłaszcza jego przemiany na przełomie XV i XVI w., tym samym nawiązując poniekąd do ustaleń Jeremy'ego Blacka, Clifforda J. Rogersa czy Roberta I. Frosta ${ }^{28}$.

Pełne omówienie stanu badań nad dziejami uzbrojenia na przełomie średniowiecza i nowożytności nie jest możliwe, choćby z uwagi na ogromny przyrost publikacji, szczególnie w odniesieniu do schyłku XV w. ${ }^{29}$ Wyraźnie dowodzi tego zestawienie najważniejszych prac poświęconych

${ }^{26}$ Na przykład dla lat: 1500-1800 w ujęciu M. Duffy'ego zob. The Military Revolution and the State 1500-1800, red. M. Duffy, Exeter 1980; 1550-1800 w ujęciu J. Blacka zob. tenże, A Military Revolution? Military Change and European Society 1550-1800, Houndmills 1991; 1300-2050 w ujęciu M. Knoxa i W. Murraya zob. The Dynamics of Military Revolution 1300-2050, red. M. Knox, W. Murray, Cambridge 2001. Kolejne przykłady można mnożyć.

${ }_{27}$ G. Agoston, dz. cyt., s. 85.

${ }^{28} \mathrm{Na}$ temat wizji rewolucji militarnej, a w szczególności roli tzw. gunpowder revolution w formie kumulatywnej zob. J. Maroń, dz. cyt., s. 28-31 (ustalenia J. Blacka), 36-37 (C.J. Rogersa), 41-44 (R.I. Frosta).

${ }^{29}$ Zob. kolejne numery „Fasciculi Archaeologiae-Historicae” i „Acta Militaria Mediaevalia". 
omawianemu zagadnieniu z ostatnich kilkudziesięciu lat (zob. tab. 1) ${ }^{30}$. Ujęto w nim najważniejsze publikacje zwarte o charakterze monograficznym. Zauważalna jest tendencja polegająca na dużym zainteresowaniu badaczy schyłkiem średniowiecza. Badania te trwaja, maja nie tylko długa metrykę, ale też prowadzone były i są przez wielu historyków. Tymczasem klasycznie rozumiana wczesna nowożytność, mimo zachowanej bogatej podstawy źródłowej, nie doczekała się aż tylu opracowań. Badań bronioznawczych oraz studiów z zakresu historii uzbrojenia dla pewnych problemów po prostu nie przeprowadzono. Rzecz jasna podejmowane sa kroki mające na celu uzupełnienie tej luki, jednak do publikacji ostatecznych ustaleń jeszcze daleko ${ }^{31}$.

Tabela 1. Stan zaawansowania badań nad uzbrojeniem wojsk pieniężnych w Polsce od połowy XV w. do $1572 \mathrm{r}$.

\begin{tabular}{|l|c|c|c|c|c|}
\hline $\begin{array}{c}\text { Wyszcze- } \\
\text { gólnienie }\end{array}$ & $\begin{array}{c}\text { Kazimierz } \\
\text { Jagiel- } \\
\text { lończyk } \\
\mathbf{( 1 4 4 7 - 1 4 9 2 )}\end{array}$ & $\begin{array}{c}\text { Jan } \\
\text { Olbracht } \\
\mathbf{( 1 4 9 2 - 1 5 0 1 )}\end{array}$ & $\begin{array}{c}\text { Aleksander } \\
\mathbf{( 1 5 0 1 - 1 5 0 6 )}\end{array}$ & $\begin{array}{c}\text { Zygmunt I } \\
\text { Stary } \\
\mathbf{( 1 5 0 6 - 1 5 4 8 )}\end{array}$ & $\begin{array}{c}\text { Zygmunt II } \\
\text { August } \\
\mathbf{( 1 5 3 0 / 1 5 4 8 -} \\
\mathbf{- 1 5 7 2}\end{array}$ \\
\hline jazda & $\mathrm{x}$ & $\mathrm{x}$ & & & $\mathrm{x}(\mathrm{cz})$ \\
\hline piechota & $\mathrm{x}$ & $\mathrm{x}$ & $\mathrm{x}$ & $\mathrm{x}$ & $\mathrm{x}(\mathrm{cz})$ \\
\hline artyleria & $\mathrm{x}$ & $\mathrm{x}$ & $\mathrm{x}$ & $\mathrm{x}($ do 1533) & \\
\hline
\end{tabular}

Legenda: $\mathrm{x}$ - badania zaawansowane; $\mathrm{x}(\mathrm{cz})$ - badania częściowe: przyczynki.

Źródło: oprac. własne.

Uzbrojeniem indywidualnym posługiwali się żołnierze przeważającej liczebnie jazdy i zazwyczaj stosunkowo nielicznej piechoty. Podstawową siłę zbrojna państwa polskiego - jazdę - tworzyło kilka formacji o mocno zróżnicowanym uzbrojeniu i strukturze organizacyjnej, a co za tym idzie przeznaczona do wykonywania różnych zadań w trakcie dozoru, przemarszu i walki. Dla omawianego okresu można przyjąć, że najczęściej występujące armatury to ciężkozbrojna kopijnicza, lekkozbrojna strzelcza, lekko-, a następnie średniozbrojna husarska oraz tzw. kozacka. $\mathrm{W}$ wyniku mieszania różnych kategorii zbrojnych w ramach jednej roty

${ }^{30}$ Szersza bibliografia do schyłku XV w. zob. P.A. Nowakowski, Bibliografia, w: Uzbrojenie w Polsce średniowiecznej 1450-1500, red. A. Nowakowski, wyd. 2, Toruń 2003, s. 328-354.

${ }^{31}$ Istotne znaczenie dla poszerzenia pola badawczego w zakresie dziejów uzbrojenia może mieć planowana publikacja ksiag skarbowo-wojskowych z 1538 i 1557 r., przygotowywana w ramach Projektu Ministra Nauki i Szkolnictwa Wyższego „Epoka jagiellońska i jej dziedzictwo w I Rzeczypospolitej do 1795 roku. Źródła do dziejów wojskowości polskiej w epoce Jagiellonów” (nr 0469/NPRH5/H30/84/2017). Kierownikiem projektu jest prof. dr hab. Jan Szymczak. 
w literaturze przedmiotu charakter oddziału określa się na podstawie przewagi ilościowej jednej z kategorii. I tak np. rota hetmańska Jana Tarnowskiego, biorąca udział w bitwie pod Obertynem w 1531 r., składała się z 109 husarzy, 130 strzelców i 45 kopijników, można ją zatem określić jako strzelecka ${ }^{32}$. Ze względu jednak na mieszany skład rot jazdy trudno określić schemat taktyczny tych oddziałów.

Podział taki jest jednak możliwy tylko do pewnego stopnia. Zaobserwować bowiem można ogromną różnorodność uzbrojenia, co skutkuje trudnościami w dokładnym określeniu armatury poszczególnych żołnierzy. Jeżeli bowiem jeździec uzbrojony po husarsku winien być zaopatrzony w drzewo, tarczę, pancerz i przyłbicę, to już np. pierwszy pocztowy w poczcie Jana Dobka (rota Hieronima Lanckorońskiego popisana w 1557 r.) miał pancerz, przyłbicę i drzewo, dosiadał zaś konia kopijniczego, to trudno jest określić, czy jest to nadal husarz (bez tarczy), czy źle wyposażony kopijnik (w pancerzu zamiast zbroi kopijniczej) ${ }^{33}$.

Mimo zasygnalizowanych problemów interpretacyjnych można jednak - w pewnym uogólnieniu - określić czas występowania poszczególnych armatur, a tym samym określonych kategorii zbrojnych. Ciężkozbrojni kopijnicy (gravis, graves, gravioris armaturae) konni w większych ilościach pojawiali się jeszcze w latach trzydziestych XVI w. Co ciekawe, przemiany typologiczno-formalne, zwłaszcza ich uzbrojenia ochronnego (przemiany zbrój płytowych), nie wpłynęły, o ile mi wiadomo, na funkcjonowanie tej formacji. Kopijnicy konni, niezależnie od tego, czy brali udział w wojnie trzynastoletniej (1454-1466), czy w wyprawie bukowińskiej Jana Olbrachta w 1497 r. (w zbrojach gotyckich), czy w wyprawach mołdawskich z lat trzydziestych XVI w., zapewne już w „renesansowych zbrojach żłobkowanych o napierśniku kulistym” (zbrojach maksymiliańskich ${ }^{34}$, nadal pełnili w wojsku tę samą funkcję. Przywołany wcześniej przykład z 1557 r. dowodzi, że nawet w latach pięćdziesiątych XVI w. nadal w niewielkiej liczbie byli obecni w szeregach jazdy zaciężnej.

Lekkozbrojni strzelcy (levis, levioris armaturae), którzy na ogół towarzyszyli kopijnikom, również odnotowywani byli u schyłku omawianego okresu, z tym że częściej występowali w drugiej połowie XV

32 AGAD, Archiwum Skarbu Koronnego (dalej: ASK), Oddział 85, sygn. 19, k. 3-12v; Z. Spieralski, Kampania obertyńska 1531 roku, Warszawa 1962, s. 220-221.

${ }^{33}$ AGAD, ASK, Oddział 85, sygn. 61, k. 42.

${ }^{34}$ A. Swaryczewski, Z. Fuiński, Napierśnik zbroi tzw. maksymiliańskiej ze zbiorów prywatnych w Krakowie, „Studia do Dziejów Dawnego Uzbrojenia i Ubioru Wojskowego" 2, 1964, s. 5, 9, przyp. 1; M. Cieśla, Napierśnik zbroi z warsztatu mediolańskiego $w$ kolekcji Muzeum Wojska Polskiego w Warszawie. Analiza porównawcza, „Studia z Dziejów Wojskowości” 7, 2018, s. 13. 
i w pierwszych dziesięcioleciach XVI w. Do tej kategorii zbrojnych można również zaliczyć lekkozbrojnych jeźdźców, którzy nie posiadali broni strzelczej. Byli nimi np. omówieni przez Tadeusza Grabarczyka gladiatores - szermierze konni, lub semihastarii - kopijnicy bez zbroi bądź w niepełnych zbrojach ${ }^{35}$.

Trzecia kategoria zbrojnych (a zatem i armatura) byli lekkozbrojni kopijnicy, czyli racowie i husarze. Te dwa określenia nie sa tożsame, oznaczaja bowiem nieco odmienne kategorie zbrojnych, jednak i jedni, i drudzy byli lekkimi konnymi kopijnikami. Badania Tadeusza Grabarczyka dowiodły, że racowie (czyli lżejsza odmiana armatury lekkokonnej kopijniczej) byli odnotowani już w $1498 \mathrm{r} .{ }^{36}$ Husarze natomiast, jak już wspomniałem, służyli regularnie w zasadzie przez cały XVI w. Zawsze występowali w pancerzu, przyłbicy, z tarczą i drzewem. Elementem najmniej czytelnym w ich uzbrojeniu była osłona głowy, tzn. przyłbica. Tę mieli także kozacy.

Pierwsza rota jazdy kozackiej została odnotowana w 1549 r. Dowodził nią Bernard Pretwicz ${ }^{37}$. W jej skład wchodziło 134 kozaków i 19 husarzy. Jazda kozacka, czyli lekka jazda strzelcza, pojawiła się zatem ponownie. Różnica polegała jednak na tym, że kozacy jako broni strzelczej używali łuku wschodniego, a prócz niego posługiwali się także rohatynami ${ }^{38}$. Chronili się przy pomocy pancerzy i przyłbic. Ponieważ wykonywali zadania wymagające dużej mobilności, szybkości i umiejętności poruszania się na dużych, otwartych przestrzeniach pogranicza południowo-wschodniego, trudno uwierzyć, by przyłbice, których używali, były zachodnioeuropejskimi hełmami zamkniętymi z ruchoma zasłoną. Niekiedy uznawano, że mogły to być szturmaki lub łebki-szłomy zaopatrzone w kołnierze kolcze ${ }^{39}$, na co jednak brak jakichkolwiek dowodów. W tym kontekście niezwykle ciekawy jest natomiast zapis pochodzący z inwentarza uzbrojenia Krzysztofa Korsaka, gdzie wymieniono m.in. „прилбиц мисурских золотом наведеных 2 , просtых

${ }^{35}$ T. Grabarczyk, Jazda zaciężna..., s. 60-63.

${ }_{36}$ Tenże, „Po racku, po husarsku, z przyprawa tatarska”-poczatki przemian wojskowości polskiej u schytku XVw., w: In tempore belli et pacis. Ludzie-miejsca-przedmioty. Ksiega pamiatkowa dedykowana prof. dr. hab. Janowi Szymczakowi w 65-lecie urodzin i 40-lecie pracy naukowo-dydaktycznej, red. T. Grabarczyk, A. Kowalska-Pietrzak, T. Nowak, Warszawa 2011, s. 117-128; tenże, Jazda zaciężna..., s. 63.

${ }^{37}$ AGAD, ASK, Oddział 85, sygn. 54, k. 18 n.

${ }_{38}$ M. Plewczyński, Kozacy w walkach z Moskwa nad Dźwina $i$ Uta $w$ latach 1567-1568, w: Od Kijowa do Rzymu. Z dziejów stosunków Rzeczypospolitej ze Stolica Apostolska $i$ Ukraina, red. M.R. Drozdowski, W. Walczak, K. Wiszowata-Walczak, Białystok 2012, s. 57.

${ }^{39}$ B. Głubisz, Jazda kozacka w armii koronnej 1549-1696, Poznań 2016, s. 53. 
прилбиц $6{ }^{\prime 40}$. Zapis ten pokazuje, że w kontekście jazdy kozackiej o typowo wschodnim charakterze przyłbicą nazywano po prostu misiurkę, która zreszta posiadając kołnierz kolczy, idealnie komponowałaby się z pancerzem (zbroją elastyczna, najczęściej kolczuga, bajdaną lub bechterem). Doceniając nowa formację i jej walory bojowe, w połowie lat pięćdziesiątych XVI w. 400 kozaków chciał zaciagnąc Albrecht Hohenzollern, przedstawiciel zachodnioeuropejskiej sztuki i myśli wojennej ${ }^{41}$.

W odróżnieniu od jazdy schemat organizacyjny oddziałów piechoty zaciężnej jest dobrze znany ${ }^{42}$. Interesująca obserwacją w przypadku piechoty jest pobieranie podwójnej stawki żołdu przez niektóre kategorie zbrojnych (kopijnicy piesi, pawężnicy, żołnierze sygnało- i rozkazodawczy). Skutkowało to obniżeniem faktycznej liczby żołnierzy w oddziale. Ubytek ten sięgał ok. 20\% w stosunku do stanu przewidzianego w liście przypowiednim (stan etatowy). W latach trzydziestych XVI w. wynosił przeciętnie $18 \%$, w kampanii obertyńskiej 1531 r. $-22 \%$, natomiast w kampanii chocimskiej 1538 r. $-16 \%{ }^{43}$.

$\mathrm{W}$ piechocie pieniężnej występowały $\mathrm{w}$ zasadzie trzy podstawowe rodzaje armatury, a zatem i trzy podstawowe kategorie zbrojnych. Pierwsza stanowili piesi kopijnicy, uzbrojeni w zbroje kopijnicze i broń drzewcowa. Wbrew obiegowej opinii nie zawsze były to tzw. drzewa. Dość często zastępowano je oszczepami, a więc bronią drzewcową o wiele bardziej nadajaca się do prowadzenia fechtunku ${ }^{44}$. Druga kategoria zbrojnych (pawężnicy) posługiwała się przede wszystkim dużymi tarczami piechoty - pawężami, które na ogół zabierano na wyprawy wojenne. Ale już piechota stacjonujacca w zamkach nie używała ich. Dobrym przykładem jest mały oddział Macieja Włodka (47 żołnierzy, 60 porcji żołdu), który zaciagnięto w 1547 r. ${ }^{45}$ Rota Włodka miała stanowić

${ }^{40}$ Biblioteka Litewskiej Akademii Nauk, Dział rękopisów, f. 16, sygn. 4, k. 23v. Informacji tej udzielił mi dr Aliaksandr Kazakou, za co serdecznie dziękuję.

${ }^{41}$ K. Eopatecki, Military Works of Albert of Hohenzollern. Comments on the Three Manuscripts Attributed to Albert of Hohenzollern in the Years 2009-2014, „Odrodzenie i Reformacja w Polsce” 2017 (publikacja internetowa, http://oir-ihpan.edu.pl/ images/2017Special_Issue/11-Lopatecki.pdf, 3 XI 2019), s. 262-263.

42 J. Wimmer, Historia piechoty polskiej do 1864 roku, Warszawa 1978, s. 104; A. Bołdyrew, Piechota zaciężna..., s. 241, 338, 339. Między tymi dwoma ujęciami sa jedynie drobne różnice.

${ }_{43}$ A. Bołdyrew, Piechota zaciężna..., s. 68-87.

${ }^{44}$ T. Grabarczyk, Piechota zaciężna..., s. 125-127; A. Bołdyrew, The Changes of the Offensive Armament of Polish Mercenary Infantry in the First art of the XVI ${ }^{\text {th }}$ Century and Their Influence on the Tactics of the Unit, w: Weapons Bring Peace? Warfare in Medieval and Early Modern Europe, red. L. Marek, Wrocław 2013, s. 221-227.

${ }^{45}$ AGAD, ASK, Oddział 85, sygn. 51, k. 53-54v. 
garnizon Kamieńca Podolskiego i zapewne dlatego żaden z jego żołnierzy nie posiadał pawęży, które wówczas jeszcze powszechnie stosowano. Ponieważ zabrakło tarcz piechoty, rację bytu straciła armatura pawężnicza, którą z roty usunięto. Miejsce pawężników zajęli zaś drudzy kopijnicy. Pawężnicy występowali przynajmniej od początku XV w. Zaniknęli ostatecznie w 1552 r., kiedy po raz ostatni zapisano ich $\mathrm{w}$ rejestrach popisowych ${ }^{46}$. Ostatnia, a jednocześnie najliczniejsza kategorią byli strzelcy. Według rejestrów popisowych z drugiej połowy XV w. stanowili oni $65-84 \%$ wszystkich żołnierzy w rotach pieszych, natomiast w pierwszej połowie XVI w. wielkość ta ustaliła się na poziomie ok. $70 \%{ }^{47}$. Zestawienie tych proporcji pokazuje, że skład rot pieszych nie ulegał dynamicznym zmianom jeśli chodzi o udział zbrojnych poszczególnych kategorii. Oczywiście w piechocie pojawiały się i inne kategorie, jak choćby bębenice, trębacze, propornicy czy cepnicy, stanowili oni jednak najwyżej kilkuprocentowe grupy.

To właśnie strzelcy są najbardziej interesująca grupą żołnierzy piechoty, których uzbrojenie warte jest kilku bardziej szczegółowych uwag. W zdecydowanej większości posługiwali się oni kuszami. Jednak już od lat siedemdziesiątych XV w. w ich rękach zaczęły się pojawiać pierwsze egzemplarze ręcznej broni palnej. Czynnik ten, uznawany za jedną z najbardziej widomych oznak rewolucji militarnej, powinien zostać odnotowany choćby z uwagi na wczesne w skali europejskiej wprowadzenie tego rodzaju broni do powszechnego użycia w armii koronnej (zob. tab. 2).

Zaprezentowane dane świadczą nie tylko o pojawieniu się ręcznej broni palnej w rękach zaciężnych piechurów stosunkowo wcześnie, bo w 1471 r. Oczywiście fakt ten można potraktować jako swego rodzaju zapowiedź dalszych przemian. Właściwa zmiana ilościowa nastapiła dopiero po kolejnych 25 latach. W 1496 r. ponad jedna czwarta strzelców wyposażona była w rusznice. Natomiast za przełomowe można uznać lata 1497 i 1498, kiedy strzelcy z rusznicami stanowili większość wśród wszystkich strzelców (odpowiednio ok. 61 i 56\%). W 1500 r. ponad $80 \%$ strzelców miało rusznice, kolejny zaś znany spis pochodzi dopiero z 1522 r. Wówczas w rocie Piotra Jasińskiego strzelcy mieli tylko i wyłącznie rusznice i choć jest to jedyny znany rejestr z tego roku, to

${ }^{46}$ T. Grabarczyk, Piechota zaciężna..., s. 171-179; A. Bołdyrew, Piechota zaciężna..., s. 258-264; tenże, Pawęże w wojsku polskim w pierwszej połowie XVI w. ( $w$ świetle rejestrów popisowych piechoty zaciężnej), w: Non sensistis gladios. Studia ofiarowane Marianowi Gtoskowi w 70. Rocznicę urodzin, red. O. Ławrynowicz, J. Maik, P.A. Nowakowski, Łódź 2011, s. 49-78.

${ }_{47}$ T. Grabarczyk, Ręczna broń palna..., s. 27-38; A. Bołdyrew, Piechota zaciężna..., s. 67. 
w kolejnych latach ta tendencja się utrzymała. Zatem moment całkowitego przestawienia się piechoty na ten rodzaj broni nastapił pomiędzy 1500 a 1522 r. Wszystkie kolejne znane rejestry odnotowują strzelców z długą ręczną bronią palną.

Tabela 2. Ręczna broń palna na uzbrojeniu polskiej piechoty zaciężnej na przełomie XV i XVI w.

\begin{tabular}{|c|c|c|c|c|c|c|}
\hline Rok & $\begin{array}{c}\text { Liczba } \\
\text { żołnierzy }\end{array}$ & $\begin{array}{c}\text { Liczba } \\
\text { strzelców }\end{array}$ & $\begin{array}{c}\text { Liczba } \\
\text { strzelców } \\
\text { z kuszami }\end{array}$ & $\begin{array}{c}\text { \% strzelców } \\
\text { z kuszami }\end{array}$ & $\begin{array}{c}\text { Liczba } \\
\text { strzelców } \\
\text { z ręczną } \\
\text { bronią palną }\end{array}$ & $\begin{array}{c}\text { \% strzelców } \\
\text { z ręczną } \\
\text { bronią palną }\end{array}$ \\
\hline 1471 & 2327 & 1780 & 1764 & 99,10 & 16 & 0,90 \\
\hline 1477 & 409 & 259 & 259 & 100 & 0 & 0 \\
\hline 1496 & 987 & 826 & 596 & 72,15 & 230 & 27,85 \\
\hline 1497 & 821 & 640 & 251 & 39,22 & 389 & 60,78 \\
\hline 1498 & 1950 & 1543 & 686 & 44,46 & 857 & 55,54 \\
\hline 1500 & 515 & 405 & 69 & 17,04 & 336 & 82,96 \\
\hline 1522 & 78 & 55 & 0 & 0 & 55 & 100 \\
\hline
\end{tabular}

Źródło: oprac. na podst. AGAD, ASK, Oddział 86, sygn. 12, t. 2, k. 1-3v; T. Grabarczyk, Ręczna broń palna $w$ świetle rejestrów popisowych piechoty zaciężnej $w$ z lat 1471-1500, „Acta Uniwersitatis Lodziensis. Folia Historica” 64, 1999, s. 31-37.

Ustalenie to wpisuje się w koncepcje stworzona przez Jana Szymczaka. Pisał on: „Obserwujac fazy rozwoju uzbrojenia zaczepnego i zwiazanego z nim uzbrojenia ochronnego w Polsce można nawet stwierdzić, iż $\mathrm{w}$ omawianym czasie [XIII-XV w. - A.B.] takie generalne przezbrajanie następowało co ok. 70 lat (lata 1290, 1360, 1430) jako efekt doświadczeń nabytych po przeprowadzeniu zakrojonych na szerszą skalę kampanii wojskowych. Znajduje to potwierdzenie nie tylko w źródłach odnoszących się do sfery produkcyjnej, ale także w ikonografii oraz dokumentach"48. Można przyjaćc, że przełom XV i XVI w. był końcem kolejnej fazy przezbrojenia, szczególnie w przypadku piechoty.

Proste konstrukcyjnie rusznice nie były jedynymi rodzajami strzelb używanych przez polską piechotę zaciężna. Z 1535 r. pochodzi pierwsza wzmianka o arkebuzie w rękach piechura. Co ciekawe, już w 1538 r. ich ilość sięgała ok. 10\% wśród broni palnej, nigdy jednak w analizowanym okresie nie przekroczyła tego poziomu ${ }^{49}$. Niejasna jest kwestia

48 J. Szymczak, Produkcja $i$ koszty uzbrojenia rycerskiego $w$ Polsce XIII-XV $w$., Łódź 1989, s. 239-240.

49 A. Bołdyrew, Arkebuzy w wojsku polskim w pierwszej połowie XVI w. ( $w$ świetle rejestrów popisowych piechoty zaciężnej), w: In tempore belli et pacis..., s. 539-550. 
modyfikacji taktyki strzału salwą po wprowadzeniu tej udoskonalonej odmiany strzelby, podobnie zreszta jak w ogóle taktyka użycia broni palnej przez piechotę. $\mathrm{O}$ ile bowiem zmiana uzbrojenia $\mathrm{z}$ kusz na rusznice jest bezdyskusyjna, to już w kwestii wykorzystania tych narzędzi walki zachodza pewne wątpliwości. System strzelania przez kuszników tzw. nawija (nawiasem) po parabolicznym torze ponad głowami współtowarzyszy pozwalał na dystansie 100-150 m od nieprzyjaciela oddać w praktyce jedna salwę. Badający te zagadnienia Tadeusz Grabarczyk twierdzi, że zastapienie kusz bronia palną nic nie zmieniło. Kilkuminutowe nabijanie rusznicy powodowało, że na tym samym dystansie, niezależnie od użytego systemu strzelania, strzelcy nadal byli w stanie oddać jeden strzał ${ }^{50}$.

W tej kwestii warte przypomnienia sa zalecenia hetmana Jana Tarnowskiego, który podkreślał, że piesi maja strzelać od pierwszego do ostatniego szeregu. Szereg, który wystrzelił, powinien przyklęknąć, by dać możliwość strzału stojącym za ich plecami ${ }^{51}$. Jednak literatura przedmiotu opisywała także inny system, polegający na strzelaniu od ostatniego szeregu, ponad głowami klęczących, bądź częściowo prostotorowo, częściowo stromotorowo (nawija) ${ }^{52}$. Bez względu na stosowany system był on w użyciu niezależnie od rodzaju broni strzelczej. Innymi słowy, choć przezbrojenie z kusz na broń palna jest faktem, to nie zmieniło ono taktyki użycia broni. Najprawdopodobniej przez cały omawiany okres piechota ustawiona w głębokim szyku (6 do 8 szeregów) strzelała tak samo. Głębokość szyku wynikała zaś z liczby żołnierzy w poszczególnych pododdziałach (dziesiątkach), w których dwóch żołnierzy (pieszy kopijnik i pawężnik) pobierali podwójną stawkę żołdu (4 stawki), a jedynie strzelcy pojedyncza (6 pozostałych stawek z 10 etatowych pozwalało zaciagnać maksymalnie 6 strzelców).

Pojawienie się broni palnej, chyba największej zmiany technicznej w uzbrojeniu wojska polskiego na przełomie średniowiecza i nowożytności,

${ }^{50}$ T. Grabarczyk, Ręczna broń palna..., s. 41-42; tenże, Piechota zaciężna..., s. 152.

${ }^{51}$ J. Tarnowski, Consilium rationis bellicae, wstęp J. Sikorski, przyg. do druku, nota, koment. i słownik T.M. Nowak, Warszawa 1987, s. 115; podobnie M. Kukiel, Zarys historii wojskowości w Polsce, b.m. i d.w., s. 52.

${ }^{52}$ K. Górski, Historia piechoty polskiej, Kraków 1893, s. 13; A. Czołowski, Bitwa pod Obertynem 22 VIII 1531, Lwów 1931, s. 20; K. Konieczny, Ręczna broń palna $w$ Polsce $w$ XV $i$ XVI w., „Muzealnictwo Wojskowe” 2, 1964, s. 202; Z. Spieralski, Wojskowość polska w okresie odrodzenia 1454-1576, w: Zarys dziejów wojskowości polskiej do roku 1864, t. 1: Do roku 1648, red. J. Sikorski, Warszawa 1965, s. 317; J. Wimmer, dz. cyt., s. 103; szerzej na ten temat zob. A. Bołdyrew, The Armament of Polish Mercenary Infantry in the First Part of the $16^{\text {th }}$ Century, „Fasciculi Archaeologiae Historicae” 27, 2014, s. 79-85. 
pociagnęło za sobą również zmiany technologiczne, a tym samym gospodarcze. Studia poświęcone produkcji uzbrojenia wyraźnie pokazuja, że rosnące zapotrzebowanie na nową broń przyczyniło się do zmian strukturalnych $\mathrm{w}$ rzemieślniczym systemie zaopatrywania żołnierzy $\mathrm{w}$ ich narzędzia walki ${ }^{53}$. Odbyło się to na dwa sposoby. Po pierwsze wymusiło przestawienie się części rzemieślników pracujących głównie w metalu na produkcję przedmiotów wymagających nowych technologii produkcyjnych. Niekompetentnym odlewnikom dzwonów groziła najwyżej utrata zarobku i prestiżu zawodowego. Pęknięcie lufy armatniej generowało o wiele dalej idace konsekwencje. Trudno bez szczegółowych nadań metaloznawczych powiedzieć więcej na ten temat. Po drugie pojawienie się podaży na broń palna, jak się wydaje, automatycznie zmniejszyło podaż na kusze. To z kolei np. w Krakowie doprowadziło do zaniku zawodu samostrzelnika (ostatni przyjęty do prawa miejskiego w $1510 \mathrm{r}$.) i przekształcenia się tego cechu $\mathrm{w}$ grzebieniarski. Zapewne samostrzelnicy jeszcze przez jakiś czas funkcjonowali w zrzeszeniu rękodzielniczym, jednak tracąc klientów, stracili jednocześnie rację bytu ${ }^{54}$. Dwa przywołane przykłady można do jakiegoś stopnia uznać za przejaw gospodarczych konsekwencji przemian charakterystycznych dla rewolucji militarnej. Zanik zawodu samostrzelnika można by porównać do zaniku znanego z piętnastowiecznych źródeł zawodu hełmiarza, którego kompetencje przeją płatnerz. Pozostaje jednak pytanie, jak znaczące było to zjawisko w skali masowej organizacji produkcji uzbrojenia i w ogóle organizacji produkcji rzemieślniczej? Kwestia ta na razie musi pozostać otwarta.

Większe zmiany zaszły na pewno w sferze społecznej. Przede wszystkim wiązały się one $\mathrm{z}$ wprowadzeniem wojsk pieniężnych. Wówczas do armii koronnej w charakterze wojowników trafiła znacznie więcej plebejuszy, niż miało to miejsce w okresie, kiedy dominowało rycerskie pospolite ruszenie. Z drugiej jednak strony plebejusze stanowili zdecydowaną większość w piechocie, będącej zaledwie towarzyszącym rodzajem broni. Zatem specyficzna gunpowder revolution, jaka miała miejsce w piechocie, w skali całej armii była chyba zjawiskiem marginalnym. W jeździe nadal (o ile można to stwierdzić na podstawie zachowanych źródeł) dominowała szlachta. Jednak i ona musiała zweryfikować swoje

53 J. Szymczak, Produkcja i koszty..., passim; tenże, Producenci i organizacja produkcji uzbrojenia, w: Uzbrojenie w Polsce średniowiecznej..., s. 131-226; A. Bołdyrew, Produkcja i koszty uzbrojenia w Polsce XVI wieku, Warszawa 2005, passim.

${ }^{54}$ J Szymczak, Od samostrzelników do grzebieniarzy $w$ Krakowi, czyli rzecz o zmierzchu znaczenia kuszy na przełomie XV $i$ XVI wieku, w: Aetas media, aetas moderna. Studia ofiarowane profesorowi Henrykowi Samsonowiczowi w siedemdziesiata rocznice urodzin, red. H. Manikowska, Warszawa 2000, s. 127-128. 
wyobrażenie o wojnie i wymaganych podczas niej kompetencji. Nowy system walki w ramach oddziałów pieniężnych, w którym nie wystarczyła przełamująca szarża rycerskiej ciężkozbrojnej jazdy kopijniczej, został chyba dość szybko zaakceptowany. Brak w każdym razie dowodów na masową obstrukcję służby wojskowej ze strony szlachetnie urodzonych. Wprost przeciwnie: Marek Plewczyński wyliczył, że nieomal połowa średniej i drobnej szlachty służyła w wojsku zaciężnym nie dłużej niż rok-dwa, co dawało żołnierzom pewne wyobrażenie o nowoczesnej wojnie, z punktu widzenia władz tworzyło zaś zasób kadrowy, do którego można było sięgnąć w przypadku większej potrzeby wojennej55. Jeśli można mówić o jakiejś zmianie mającej rewolucyjny charakter, to raczej na płaszczyźnie mentalnościowej. Dopuszczenie do służby w wojsku plebejuszy mogło wpłynąć na złamanie fantazmatu szlachcic - defensor patriae. Celowo używam trybu przypuszczającego, ponieważ mogło dojść do takiego zjawiska, a skądinąd wiadomo, że mimo wyraźnych zmian w strukturze armii i jej zasobie kadrowym tak się nie stało.

Choć pewne przejawy przemian w uzbrojeniu wojska polskiego w latach 1454-1572 można uznać za odpowiedniki dystynktywnych cech rewolucji militarnej definiowanych przez Michaela Robertsa, Geoffreya Parkera, Clifforda J. Rogersa, Jeremy'ego Blacka i innych, to jednak z punktu widzenia czystej definicji rewolucji przemiany, które miały miejsce w realiach Królestwa Polskiego, nie spełniają wymogów „rewolucyjności”. Jeśli bowiem założymy, że ta musi mieć w sobie element dynamicznej przemiany ilościowej lub jakościowej, a towarzyszyć temu może czynnik ludzki w postaci tzw. aktanta (osoby będącej motorem/ inicjatorem zmian), to trudno dopatrzyć się ich w zaprezentowanym materiale ${ }^{56}$. Oczywiście materiał przyjęty w niniejszym opracowaniu jako podstawa nie jest pełny. Brak w nim - jak już wspomniałem - wielu badań podstawowych. Również przyjęty okres jest może zbyt wczesny, jeśli chodzi o porównanie realiów zachodnio- i środkowoeuropejskich. Podobnie jest z kwestią oznaczenia aktanta. Przyjęcie, że funkcję taka mógł pełnić hetman Jan Tarnowski (1488-1561) nie jest ustaleniem nowym. Decydująca lub znaczacca jego rola w wielu obszarach, w tym

${ }_{55}$ M. Plewczyński, Żotnierz jazdy..., s. 238-243.

56 Szeroko na temat rewolucji w ujęciu szkoły tartusko-moskiewskiej zob. B. Żyłko, Kultura i znaki. Semiotyka stosowana $w$ szkole tartusko-moskiewskiej, Gdańsk 2011, s. $84-85$. 
również w kontekście przemian w masowym uzbrojeniu wojska polskiego, podkreślana była w literaturze przedmiotu wielokrotnie ${ }^{57}$.

Czy na podstawie zaprezentowanego materiału można zatem stwierdzić, że rewolucji militarnej w Polsce na przełomie XV i XVI w. nie było? W skali ogólnej - tak, jednak można dostrzec przynajmniej jeden jej przejaw, skoro na pierwsze lata XVI w. przypadła tzw. gunpowder revolution ${ }^{58}$. Wprowadzenie na użytek wojska indywidualnej broni palnej można uznać za dynamiczną zmianę jakościową i ilościowa, przy zastrzeżeniu marginalności zjawiska w skali armii i państwa. Jednakże w rozumieniu rewolucji militarnej jako „political revolution occasioned by military change" niezbędny wydaje się komponent zmiany politycznej, a tego trudno się doszukać na przełomie XV i XVI w., w myśl założeń koncepcji postulowanej najpierw przez Michaela Robertsa, a następnie Roberta I. Frosta ${ }^{59}$.

Obserwowane zjawiska miały więc charakter raczej powolnej przemiany dopełnionej momentami dynamicznych przekształceń ${ }^{60}$, zatem „military change was not so much revolutionary, as evolutionary, taking place gradually from the late fifteenth century as commanders sought various ways of using and combating the new technology of gunpowder weapons" ${ }^{61}$. Niezależnie od przyjętego wyjaśnienia, nie da się bowiem negować roli broni palnej w wojskach polsko-litewskich (przynajmniej od schyłku XV w.). Zatem być może należy postawić kolejną hipotezę: o specyficznej drodze rozwoju wojskowości środkowoeuropejskiej, która trudno przełożyć w prosty sposób na doświadczenia Europy Zachodniej. Uważam, że przemiany wojskowości polskiej od schyłku XV do końca XVI w. cechowały się tak dużą odmiennością od uwzględnionych w klasycznej teorii rewolucji militarnej, że w przypadku większości porównań

${ }^{57}$ A. Bołdyrew, Czy hetman Jan Tarnowski byt inicjatorem reformy uzbrojenia?, w: Mieczem i szczytem. Broń na polu walki. Z dziejów wojskowości polskiej i powszechnej, red. A. Niewiński, Oświęcim 2016, s. 79-86, gdzie dalsza literatura. Dziękuję prof. Karolowi Łopateckiemu za zwrócenie uwagi na tzw. czynnik dynamizujaccy prawa (w tym przypadku artykułów rotmistrzowskich) w kontekście przemian w uzbrojeniu; por. K. Łopatecki, Czy Jan Tarnowski jest twórca prawa wojskowego na terenie Korony $i$ Wielkiego Księstwa Litewskiego?, w: Kultura społeczna i religijna Matopolski od XIII do XVI wieku, red. W. Szymborski, J. Kozioł, Tarnów 2011, s. 13-21; tenże, „Disciplina militaris”..., s. 61-63, 69 n., 82 n., 134; zagadnienie to, leżące na pograniczu historii prawa wojskowego i historii uzbrojenia, zasługuje na osobne studium.

${ }^{58}$ Pojęcia tego używam w odniesieniu do ręcznej broni palnej. Zespołowa broń palna wymaga dalszych, szczegółowych badań.

${ }_{59}$ R.I. Frost, The Polish-Lithuanian Commonwealth..., s. 20.

60 Tak w ujęciu C.J. Rogersa i R.I. Frosta; zob. J. Maroń, dz. cyt., s. 37, 44.

${ }^{61}$ R.I. Frost, The Polish-Lithuanian Commonwealth..., s. 20. 
można mówić jedynie o „protokole rozbieżności”. Czy mamy zatem do czynienia z - parafrazujacc Geoffreya Parkera - trace polonais (w odniesieniu nie tylko do systemu fortyfikacji, ale ogólnie całokształtu spraw wojskowych), ewentualnie via Polonica? Ta propozycja w jakiejś mierze wydaje się tworzyć płaszczyznę do przynajmniej częściowego uwzględnienia ustaleń badaczy zachodnioeuropejskich w odniesieniu do dziejów polskiej wojskowości ${ }^{62}$.

Pierwsza, nasuwającą się uwaga, która w jakiejś mierze charakteryzowałaby odmienność via Polonica od innych dróg, którymi przebiegała rewolucja militarna w Europie Zachodniej, jest stwierdzenie, że pewne elementy w dziejach wojskowości polskiej (szczególnie od przełomu XV i XVI w. aż do schyłku XVI w.), które można by uznać za przejawy rozpoczynającej się rewolucji, faktycznie zaistniały. Jednak konsekwencje, które przyniosły na Zachodzie, już nie. I tak np. bez wątpliwości można określić moment masowego przezbrojenia żołnierzy piechoty z kusz w ręczną broń palna. Zatem etap pierwszy (gunpowder revolution) ewidentnie miał miejsce. Jak pisał John F. Guilmartin jr. w odniesieniu do Turcji: „In fact, the Ottomans paralleled and at times anticipated the military revolution, notably in early adoption of individual gunpowder weapons and in the creation of an elaborate, efficient and well-articulated bureaucracy dedicated to the prosecution of war"63. O ile pierwszy wyznacznik (early adoption of individual gunpowder weapons) jak najbardziej miał miejsce w Polsce, o tyle drugi - wytworzenie sprawnego systemu finansowania wojny - już nie.

System finansowania wojska zawodził długo po wprowadzeniu broni palnej. W 1535 r. zakończone sukcesem czterotygodniowe oblężenie Starodubu w zasadzie nic nie dało. Zawiodło bowiem nie wojsko, zgromadzono nawet - jak się wydaje - odpowiednią ilość piechoty, artylerii i inżynierów, zawiódł niewydolny system skarbowo-wojskowy. Nieopłaceni na czas żołnierze wycofali się, pozostawiając zdobycze terytorialne bez odpowiedniego dozoru, co pozwoliło w 1536 r. siłom moskiewskim odbić utracone ziemie ${ }^{64}$. Zresztą brak reformy biurokratyczno-skarbowej

${ }^{62} \mathrm{O}$ „wyjściu poza zaklęty krag Francji, Niderlandów, Włoch i zachodnich Niemiec" zob. J. Maroń, dz. cyt., s. 77.

63 J.F. Guilmartin jr., The Military Revolution. Origins and First Tests Abroad, w: The Military Revolution Debate. Readings on the Military Transformation of Early Modern Europe, red. C.J. Rogers, Boulder 1995, s. 303.

${ }^{64}$ Acta Tomiciana. Epistolarum, legationum, responsorum, actionum et rerum gestarum Serenissimi Principis Sigismundi Primi regis Poloniae Magni Ducis Lithuaniae per Stanislausm Górski canonicum Cracoviensem et Plocensem collectarum, t. 17, wyd. W. Pociecha, Poznań 1966, nr 140, 532; W. Dworzaczek, Hetman Jan Tarnowski. 
dał się odczuć już wcześniej, choćby podczas prób przeprowadzenia tzw. relucji pospolitego ruszenia. $\mathrm{Z}$ braku miejsca nie można tu rozwinąc tego zagadnienia, jak również problemu innych prób reform skarbowo-wojskowych, warto jednak podkreślić, że akcja podjęta w latach 1527-1529 (w Małopolsce w 1536 r.), mimo dużego zaawansowania, została oprotestowana przez szlachtę. Przeprowadzona w 1532 r. tzw. korektura praw utrzymała przywileje wojskowe szlachty, hamując rozwój nowoczesnego skarbu wojskowego ${ }^{65}$. Tu właśnie widziałbym różnicę między przebiegiem przemian w Polsce i Turcji oraz odmienność tych dwóch od modelu klasycznego - zachodnioeuropejskiego.

Kolejną kwestia godna odnotowania jest współdziałanie rodzajów broni na polu walki ${ }^{66}$. Począwszy od starcia pod Świecinem, poprzez bitwy po Orsza, Obertynem i Lubiszewem można obserwować stosowanie tej zasady sztuki wojennej przez wojsko polskie ${ }^{67}$. Cóż jednak z tego, jeżeli zjawisku tactical innovation winna towarzyszyć administrative innovation. Osobna kwestia jest, czy wschodni teatr działań wojennych sprzyjał rozwijaniu kombinowanych sił na modłę zachodnią. Ten czynnik wraz z dominacją w przeważającej liczebnie jeździe „narodu politycznego", który choćby w przywołanej korekturze z 1532 r. obronił swoją dominująca pozycję, w zasadzie wykluczał możliwość głębszych zmian. Najwyraźniej w ówczesnym kontekście polityczno-społeczno-gospodarczym wymagałoby to przynajmniej częściowego ustapienia szlachty z pozycji dominanta politycznego i głównego beneficjenta rodzacej się demokracji szlacheckiej. Brak centralnego, sprawnego systemu skarbowo-wojskowego uważam za podstawowy czynnik, który (mimo sprzyjających okoliczności technicznych i technologicznych) uniemożliwił zaistnienie tzw. rewolucji militarnej w Polsce w omawianym okresie ${ }^{68}$.

Z dziejów możnowtadztwa małopolskiego, Warszawa 1985, s. 74-75; Z. Spieralski, Wojskowość..., s. 344; tenże, Jan Tarnowski 1485-1561, Warszawa 1977, s. 257, 260; A. Bołdyrew, Piechota zaciężna..., s. 327.

${ }_{65}$ J. Senkowski, Materiaty źródtowe do genezy skarbu publicznego $w$ Polsce w Archiwum Głównym Akt Dawnych w Warszawie, „Archeion” 23, 1954, s. 30, 33; W. Uruszczak, Próba kodyfikacji prawa polskiego $w$ pierwszej połowie XVI wieku. Korektura praw z 1532 r., Warszawa 1979, s. 195; tenże, Korektura praw z 1532 roku. Studium historycznoprawne, t. 1-2, Warszawa 1990-1991, passim; A. Bołdyrew, Piechota zaciężna..., s. 89, 93, 97-99.

66 Tzw. „combined arms revolution”; zob. J.F. Guilmartin jr., dz. cyt., s. 307.

${ }^{67} \mathrm{Na}$ temat zasad sztuki wojennej zob. D. Strasburger, Zasady sztuki wojennej $w$ kampaniach $i$ bitwach od starożytności do wojny francusko-pruskiej 1870-1871, Warszawa 1996, s. 21-23.

${ }^{68} \mathrm{Na}$ temat wpływu zmian technicznych i technologicznych na możliwości powiększenia armii zob. K. Łopatecki, Rewolucja militarna, w: J. Kunowski, Ekspedycyja inflatska 1621 roku, wyd. K. Łopatecki, W. Walczak, Białystok 2007, s. 84. 
Zatem na taki stan rzeczy wpłynęły nie braki „infrastrukturalne”, lecz świadomościowe. Warto tu odnieść się do prawidła sformułowanego przez Fredrica Jamesona ${ }^{69}$. Twierdził on, że składnikami nowoczesności (modernity) sa modernizacja (modernization) i modernizm (modernism). Modernizację rozumie jako przemiany ,infrastrukturalne”, natomiast mianem modernizmu określa zmiany społeczno-kulturowe towarzyszące zmianom w sferze materialnej. Brak przemiany na poziomie abstrakcji uniemożliwia zaistnienie pożądanego stanu nowoczesności. Można więc zaryzykować stwierdzenie, że cechą charakterystyczna via Polonica był dość szybko pojawiajacy się czynnik materialny ${ }^{70}$, zabrakło natomiast mentalnej zmiany: pragmatycznej i dalekowzrocznej. Przemiany w obszarze uzbrojenia wojska polskiego w omawianym okresie miały zatem w zdecydowanej większości charakter przeobrażeń ewolucyjnych. Innymi słowy, można - jak się wydaje - przyjąć, przy pewnych zastrzeżeniach, że rewolucja militarna (w postaci gunpowder revolution) rozpoczęła się w Polsce stosunkowo wcześnie, ale - nomen omen - „spaliła na panewce".

\section{Bibliografia}

\section{Źródła}

Acta Tomiciana. Epistolarum, legationum, responsorum, actionum et rerum gestarum Serenissimi Principis Sigismundi Primi regis Poloniae Magni Ducis Lithuaniae per Stanislausm Górski canonicum Cracoviensem et Plocensem collectarum, t. 17, wyd. W. Pociecha, Poznań 1966.

Pamiętniki do historyi Stefana króla polskiego, wyd. E. Raczyński, Warszawa 1830.

Tarnowski J., Consilium rationis bellicae, wstęp J. Sikorski, przyg. do druku, nota, koment. i słownik T.M. Nowak, Warszawa 1987.

69 F. Jameson, Postmodernism, or, The Cultural Logic of Late Capitalism, London 1991, s. 310; J. Sowa, Fantomowe ciato króla. Peryferyjne zmagania z nowoczesna forma, Kraków 2011, s. 529.

${ }^{70}$ Obiecująca w tym kontekście ścieżką badawczą wydają się studia nad tzw. reforma kozacką z połowy XVI w. Jednak na prezentację wniosków jest jeszcze zbyt wcześnie. 


\section{Opracowania}

Agoston G., Firearms and Military Adoption. The Ottomans and the European Military Revolution, 1450-1800, „Journal of World History” 25, 2014, nr 1, s. $85-124$.

Bennett M., Bradbury J., DeVries K., Dickie J., Jestice P., Fighting Techniques of the Medieval World, $A D 500$ - AD 1500, New York 2005.

Biskup M., Trzynastoletnia wojna z Zakonem Krzyżackim 1454-1466, Warszawa 1967.

Black J., A Military Revolution? Military Change and European Society 1550 -1800, Houndmills 1991.

Bołdyrew A., Arkebuzy w wojsku polskim w pierwszej połowie XVI w. (w świetle rejestrów popisowych piechoty zaciężnej), w: In tempore belli et pacis. Ludzie - miejsca - przedmioty. Ksiega pamiatkowa dedykowana prof. dr. hab. Janowi Szymczakowi w 65-lecie urodzin i 40-lecie pracy naukowo-dydaktycznej, red. T. Grabarczyk, A. Kowalska-Pietrzak, T. Nowak, Warszawa 2011, s. 539-550.

Bołdyrew A., The Armament of Polish Mercenary Infantry in the First Part of the $16^{\text {th }}$ Century, „Fasciculi Archaeologiae Historicae” 27, 2014, s. 79-85.

Bołdyrew A., The Changes of the Offensive Armament of Polish Mercenary Infantry in the First art of the XVI ${ }^{\text {th }}$ Century and Their Influence on the Tactics of the Unit, w: Weapons Bring Peace? Warfare in Medieval and Early Modern Europe, red. L. Marek, Wrocław 2013, s. 221-227.

Bołdyrew A., Czy hetman Jan Tarnowski byt inicjatorem reformy uzbrojenia?, w: Mieczem i szczytem. Broń na polu walki. Z dziejów wojskowości polskiej i powszechnej, red. A. Niewiński, Oświęcim 2016, s. 79-86.

Bołdyrew A., Jan Ciemierzyński's Comitiua. A Preliminary Study of the History of Defence of the South-Eastern Borderland during the Poswole Expedition of Sigismund II Augustus (1557), w: War in History. The History of Polish and General Military Service, red. A. Niewiński, Lublin 2017, s. $103-114$.

Bołdyrew A., Pawęże w wojsku polskim w pierwszej połowie XVI w. (w świetle rejestrów popisowych piechoty zaciężnej), w: Non sensistis gladios. Studia ofiarowane Marianowi Głoskowi w 70. Rocznice urodzin, red. O. Ławrynowicz, J. Maik, P.A. Nowakowski, Łódź 2011, s. 49-78.

Bołdyrew A., Piechota zaciężna $w$ Polsce $w$ pierwszej połowie XVI wieku, Warszawa 2011.

Bołdyrew A., Produkcja i koszty uzbrojenia w Polsce XVI wieku, Warszawa 2005.

Bołdyrew A., Przemarsz armii koronnej pod Chocim w kampanii letniej 1538 r. (w druku).

Bołdyrew A., Rota drabska pana Aleksandra Kosińskiego (1569 r.) (w druku).

Bołdyrew A., Rota piesza Antoniego Mory z 1553 r. Studium przypadku, w: Studia nad staropolska sztuka wojenna, t. 4, red. Z. Hundert, K. Żojdź, J.J. Sowa, Oświęcim 2015, s. 15-26. 
Burliga B., „Ordunki” versus „arkebuzy dymiqce”. Tradycja i nowoczesność $w$ „Księgach o rycerskich rzeczach (Kreigsordnung)” księcia Albrechta von Hohenzollerna, w: Organizacja armii w nowożytnej Europie: struktura urzędy - prawo - finanse, red. K. Łopatecki, Zabrze 2011, s. 47-61.

Chojecki A., Oczywistość, „Er(r)go. Teoria - Literatura - Kultura” 1-2 (18-19), 2009, s. 59-72.

Cieśla M., Napierśnik zbroi z warsztatu mediolańskiego $w$ kolekcji Muzeum Wojska Polskiego w Warszawie. Analiza porównawcza, „Studia z Dziejów Wojskowości" 7, 2018, s. 7-55.

Czołowski A., Bitwa pod Obertynem 22 VIII 1531, Lwów 1931.

Dangl V., Kopčan V., Vojenské dejiny Slovenska, II zväzok 1526-1711, Bratislava 1995.

Dworzaczek W., Hetman Jan Tarnowski. Z dziejów możnowtadztwa małopolskiego, Warszawa 1985.

The Dynamics of Military Revolution 1300-2050, red. M. Knox, W. Murray, Cambridge 2001.

Eltis D., The Military Revolution in Sixteenth-Century Europe, New York 1995.

Frost R.I., The Polish-Lithuanian Commonwealth and the „Military Revolution”, w: Poland and Europe: Historical Dimensions. Selected Essays from the Fiftieth Anniversary International Congress of the Polish Institute of Arts and Sciences in America, t. 1, red. J.S. Pula, M.B. Biskupski, New York 1993, s. 19-47.

Frost R.I., W sprawie zachodniej techniki wojskowej w okresie Wojen Pótnocnych (1558-1721), w: Między Zachodem a Wschodem. Studia z dziejów Rzeczypospolitej w epoce nowożytnej, red. J. Staszewski, K. Mikulski, J. Dumanowski, Toruń 2002, s. 293-300.

Gawron P., Poglady Stanistawa Herbsta na rozwój nowożytnej sztuki wojennej a teoria „Rewolucji Militarnej”, w: Wojsko, wojskowość, miasta. Studia poświęcone Prof. Stanisławowi Herbstowi w stulecie urodzin, red. K. Bobiatyński, P. Gawron, M. Nagielski, Zabrze 2009, s. 153-164.

Ginter K., Udziat szlachty polskiej $w$ pospolitym ruszeniu $w$ XIV $i$ XV wieku. Aspekty prawne i stan faktyczny, Kraków 2008.

Głubisz B., Jazda kozacka w armii koronnej 1549-1696, Poznań 2016.

Górski K., Historia piechoty polskiej, Kraków 1893.

Grabarczyk T., Jazda zaciężna Królestwa Polskiego w XV wieku, Łódź 2015.

Grabarczyk T., Piechota zaciężna Królestwa Polskiego w XV wieku, Łódź 2000.

Grabarczyk T., „Po racku, po husarsku, z przyprawa tatarska”- poczatki przemian wojskowości polskiej u schytku XV w., w: In tempore belli et pacis. Ludzie - miejsca - przedmioty. Księga pamiatkowa dedykowana prof. dr. hab. Janowi Szymczakowi $w$ 65-lecie urodzin i 40-lecie pracy naukowo-dydaktycznej, red. T. Grabarczyk, A. Kowalska-Pietrzak, T. Nowak, Warszawa 2011, s. 117-128.

Grabarczyk T., Ręczna bron palna w świetle rejestrów popisowych piechoty zaciężnej $w$ z lat 1471-1500, „Acta Uniwersitatis Lodziensis. Folia Historica" 64,1999 , s. $27-48$. 
Guilmartin J.F. jr., The Military Revolution. Origins and First Tests Abroad, w: The Military Revolution Debate. Readings on the Military Transformation of Early Modern Europe, red. C.J. Rogers, Boulder 1995, s. 299-333.

Jameson F., Postmodernism, or, The Cultural Logic of Late Capitalism, London 1991.

Kazakou A., Gunpowder Revolution in the East of Europe and the Battle of Orša, 1514 (w druku).

Konieczny K., Ręczna broń palna $w$ Polsce $w$ XV $i$ XVI $w$., „Muzealnictwo Wojskowe" 2, 1964, s. 167-237.

Koranyi K., Żołnierz najemny a żotnierz zaciężny, CPH, t. 1, 1948, s. 105-108.

Kotarski H., Wojsko polsko-litewskie podczas wojny inflanckiej 1576-1582. Sprawy organizacyjne, „Studia i Materiały do Historii Wojskowości” 17, 1971, nr 1, s. 51-124 (cz. 2), nr 2, s. 81-151 (cz. 3), 18, 1972, nr 1, s. 3-92 (cz. 4), nr 2, s. 43-104 (cz. 5).

Kukiel M., O podziale polskiej historii wojskowej na okresy, „Przegląd Współczesny" 7, 1928, nr 1, s. 63-81.

Kukiel M., Zarys historii wojskowości w Polsce, b.m. i d.w.

Łopatecki K., Czy Jan Tarnowski jest twórca prawa wojskowego na terenie Korony $i$ Wielkiego Księstwa Litewskiego?, w: Kultura społeczna i religijna Małopolski od XIII do XVI wieku, red. W. Szymborski, J. Kozioł, Tarnów 2011, s. 13-21.

Łopatecki K., „Disciplina militaris” w wojskach Rzeczypospolitej do połowy XVII wieku, Białystok 2012.

Łopatecki K., Military Works of Albert of Hohenzollern. Comments on the Three Manuscripts Attributed to Albert of Hohenzollern in the Years 2009 -2014, „Odrodzenie i Reformacja w Polsce” 2017 (publikacja internetowa, http://oir-ihpan.edu.pl/images/2017Special_Issue/11-Lopatecki.pdf, 3 XI 2019), s. 245-273 (pierwodruk: Twórczość wojskowa Albrechta Hohenzollerna. Uwagi nad trzema manuskryptami przypisanymi w latach 2009 -2014 Albrechtowi Hohenzollernowi, „Odrodzenie i Reformacja w Polsce” 59, 2015, s. 163-188).

Łopatecki K., Organizacja, prawo i dyscyplina $w$ polskim i litewskim pospolitym ruszeniu do połowy XVII wieku, Białystok 2012.

Łopatecki K., Rewolucja militarna, w: J. Kunowski, Ekspedycyja inflatska 1621 roku, wyd. K. Łopatecki, W. Walczak, Białystok 2007.

Łopatecki K., U genezy państwowej opieki społecznej i zdrowotnej - szpitalnictwo wojskowe $w$ epoce nowożytnej, „Medycyna Nowożytna” 22, 2016, nr 1, s. 55-77.

Maroń J., Wokół teorii rewolucji militarnej. Wybrane problemy, Wrocław 2011.

The Military Revolution and the State 1500-1800, red. M. Duffy, Exeter 1980.

Nowakowski P.A., Bibliografia, w: Uzbrojenie w Polsce średniowiecznej 1450 -1500 , red. A. Nowakowski, wyd. 2, Toruń 2003, s. 328-354.

Olejnik K., Stefan Batory 1533-1586, Warszawa 1988. 
Olzacka E., Wojna a kultura. Nowożytna rewolucja militarna $w$ Europie Zachodniej i Rosji, Kraków 2016.

Parker G., The „Military Revolution”, 1560-1660 - a Myth?, „The Journal of Modern History" 48, 1976, nr 2, s. 195-214.

Parker G., The Military Revolution. Military Innovation and the Rise of the West, 1500-1800, Cambridge 1996.

Paul M.C., The Military Revolution in Russia, 1550-1682, „The Journal of Military History" 68, 2004, nr 1, s. 9-45.

Plewczyński M., Kozacy w walkach z Moskwa nad Dźwina $i$ Uta w latach 1567-1568, w: Od Kijowa do Rzymu. Z dziejów stosunków Rzeczypospolitej ze Stolica Apostolska i Ukraina, red. M.R. Drozdowski, W. Walczak, K. Wiszowata-Walczak, Białystok 2012, s. 57-72.

Plewczyński M., Materiały do zagadnienia liczebności i organizacji wojska polskiego $w$ latach 1526-1547, „Studia i Materiały do Historii Wojskowości” 32, 1989, s. 249-269.

Plewczyński M., Żotnierz jazdy obrony potocznej za czasów Zygmunta Augusta. Studia nad zawodem wojskowym w XVI w., Warszawa 1985.

Poe M., The Military Revolution, Administrative Development, and Cultural Change in Early Modern Russia, „Journal of Early Modern History” 2, 1998, nr 3, s. 247-273.

Raymond J., Henry VIII's Military Revolution. The Armies of Sixteenth-Century Britain and Europe, London 2007.

Senkowski J., Materiaty źródtowe do genezy skarbu publicznego w Polsce w Archiwum Głównym Akt Dawnych w Warszawie, „Archeion” 23, 1954, s. $28-48$.

Sowa J., Fantomowe ciało króla. Peryferyjne zmagania z nowoczesna forma, Kraków 2011.

Sowa J.J., O prawnych aspektach dyscypliny w sitach zbrojnych Rzeczypospolitej. Na marginesie najnowszych prac Karola Eopateckiego, CPH, t. 66, 2014, nr 1, s. 439-450.

Spieralski Z., Jan Tarnowski 1485-1561, Warszawa 1977.

Spieralski Z., Kampania obertyńska 1531 roku, Warszawa 1962.

Spieralski Z., Wojskowość polska w okresie odrodzenia 1454-1576, w: Zarys dziejów wojskowości polskiej do roku 1864, t. 1: Do roku 1648, red. J. Sikorski, Warszawa 1965, s. 244-351.

Srogosz T., Życie codzienne żotnierzy armii koronnej i litewskiej $w$ XVII wieku, Oświęcim 2018.

Strasburger D., Zasady sztuki wojennej w kampaniach i bitwach od starożytności do wojny francusko-pruskiej 1870-1871, Warszawa 1996.

Swaryczewski A., Fuiński Z., Napierśnik zbroi tzw. maksymiliańskiej ze zbiorów prywatnych w Krakowie, „Studia do Dziejów Dawnego Uzbrojenia i Ubioru Wojskowego" 2, 1964, s. 5-9.

Szadkowski P., Staropolskie i hiszpańskie piśmiennictwo wojskowe XVI wieku $w$ kontekście teorii rewolucji militarnej. Próba porównania, KH, t. 125, 2018, nr 3, s. 597-631. 
Szymczak J., Od samostrzelników do grzebieniarzy w Krakowi, czyli rzecz o zmierzchu znaczenia kuszy na przetomie XV $i$ XVI wieku, w: Aetas media, aetas moderna. Studia ofiarowane profesorowi Henrykowi Samsonowiczowi w siedemdziesiata rocznice urodzin, red. H. Manikowska, Warszawa 2000 , s. $122-128$.

Szymczak J., Poczatki broni palnej w Polsce (1383-1533), Łódź 2004.

Szymczak J., Producenci $i$ organizacja produkcji uzbrojenia, w: Uzbrojenie $w$ Polsce średniowiecznej 1450-1500, red. A. Nowakowski, wyd. 2, Toruń 2003, s. 131-226.

Szymczak J., Produkcja i koszty uzbrojenia rycerskiego $w$ Polsce XIII-XV w., Łódź 1989.

Uruszczak W., Korektura praw z 1532 roku. Studium historycznoprawne, t. 1-2, Warszawa 1990-1991.

Uruszczak W., Próba kodyfikacji prawa polskiego w pierwszej połowie XVI wieku. Korektura praw z 1532 r., Warszawa 1979.

Wimmer J., Historia piechoty polskiej do 1864 roku, Warszawa 1978.

Wypisy źródłowe do historii polskiej sztuki wojennej, z. 4: Polska sztuka wojenna w latach 1454-1562, oprac. Z. Spieralski, Warszawa 1958.

Żyłko B., Kultura $i$ znaki. Semiotyka stosowana w szkole tartusko-moskiewskiej, Gdańsk 2011.

Aleksander Bołdyrew

Changes in the armament of the Polish Army at the turn of the Middle Ages and the Early Modern Period (1454-1572) as a sign of military (r)evolution

(Summary)

The article analyzes the changes in the armament of the Polish Army soldiers at the turn of the Middle Ages and the early modern period from the point of view of the theory of military revolution. It discusses changes in the equipment of cavalry soldiers (lancers, marksmen, hussars, Cossacks) and infantrymen (lancers, pavise-bearers, marksmen). The greatest change could be observed in the armament of infantry marksmen, who in the years 1500-1522 completely abandoned crossbows and started using long firearms. This corresponds to one of the characteristic features of military revolution, namely the so-called gunpowder revolution. Following this thread, it was attempted to indicate the emergence of broader transformations which could be interpreted as a consequence of the military revolution in Western Europe. However, the analysis of the phenomenon showed that the changes in armament were not followed by dynamic transformations in the military administration forced to manage a newly modernized army, and that the system of financing the military was far from efficient. The article also points to several potential causes for such a state of affairs. Among these, the most important 
one was the dominant position of nobility in the country, including the army, which largely impeded the implementation of the so-called fiscal-military reforms (i.a. reluition of the levée en masse).

Aleksander Bołdyrew - dr hab., prof. Uniwersytetu Łódzkiego w Katedrze Historii Średniowiecznej Instytutu Historii. Zajmuje się historią wojskowości (szczególnie techniki wojskowej), a także kultury materialnej i gospodarczej epoki jagiellońskiej. Autor monografii: Produkcja i koszty uzbrojenia $w$ Polsce XVI wieku, Warszawa 2005; Piechota zaciężna w Polsce w pierwszej połowie XVI wieku, Warszawa 2011; Equus Polonus. Koń w wojsku polskim w XVI wieku, Piotrków Trybunalski 2016.

Aleksander Boldyrew - $\mathrm{PhD}$ with habilitation, professor at the Department of Medieval History of the History Institute, University of Łódź. His academic interests focus on the history of the military (particularly military technology), history of material culture, and economic history of the Jagiellon era. Author of monographic works: Produkcja i koszty uzbrojenia $w$ Polsce XVI wieku, Warsaw, 2005; Piechota zaciężna $w$ Polsce $w$ pierwszej połowie XVI wieku, Warsaw, 2011; Equus Polonus. Kon w wojsku polskim w XVI wieku, Piotrków Trybunalski, 2016.

E-mail: aleksander.boldyrew@uni.lodz.pl. 